\title{
KONSEP ADIL DALAM HUKUM WARIS ISLAM
}

\author{
Fadlih Rifenta \\ Universitas Darussalam Gontor, putratalawi1990@gmail.com
}

\author{
Diterima: 3 Maret $2018 \quad$ Direvisi: 17 April $2018 \quad$ Diterbitkan: 30 Juni 2018
}

\begin{abstract}
The science which is lost first among muslim community is the knowledge of inheritance as Rasulullah had been explained. Moreover, there are some efforts to destroy the inheritance law arrangement in islam. By the opinion that the division of inheritance that for son is equal with two daughters is a form of injustice toward woman. Therefore, it is allowed to create modification for Islamic inheritance law. This paper tries to explain the justice concept in Islamic inheritance law. By the conclusion that, First; the definition of Islamic inheritance law has to follow the determination by Allah SWT and it does not mean that equal division is equal quantity. Second; in the case of inheritance division in islam, it contains the universal justice according to theology, economic and social.
\end{abstract}

Keywords: Justice, Inheritance Law, Islam.

\begin{abstract}
Abstrak
Ilmu yang pertama kali bilang ditengah kaum muslimin adalab ilmu waris, sebagaimana yang telah disampaikan oleb Rasulullab SAW. Tidak hanya sampai disitu, adanya usaha untuk merusak tatanan bukum waris dalam Islam. Dengan anggapan bahwa pembagian harta warisan bagi seorang anak laki-laki sebanding dengan dua orang anak perempuan merupakan sebuah bentuk kezaliman terhadap perempuan. Sehingga diperbolebkean untuk melakukan modifikasi terhadap bukum waris Islam. makalah ini berusah untuk menjelaskan konsep adil dalam hukum waris Islam. Dengan kesimpulan bahwa, Pertama; Makna keadilan dalam bukum waris Isläm barus mengikuti ketentunan Allah SWT bukan pembagian yang sama rata. Kedua; Dibalik pembagian waris dalam Isläm mengandung keadilan yang bersifat Universal ditinjau dari sisi teologi, ekonomi, sosial.
\end{abstract}

Kata Kunci: Adil, Hukum Waris, Islam.

\section{PENDAHULUAN}

Proses perjalanan kehidupan manusia di dunia adalah lahir, hidup, dan mati, semua tahapan itu membawa pengaruh dan akibat hukum terhadap lingkungannya, terutama dengan orang yang dekat dengannya, baik dekat dalam arti nasab maupun dalam arti lingkungan. Kelahiran membawa akibat timbulnya hak dan kewajiban bagi dirinya dan orang lain serta timbulnya hubungan hukum antara dia dengan orangtua, kerabat, dan masyarakat lingkungannya. Selama hidupnya, sejak proses bayi, anak-anak, tamyiz, usia baligh dan usia selanjutnya, manusia bertindak sebagai penanggung hak dan kewajiban, baik selaku pribadi, anggota keluarga, warga Negara, taat dan patuh kepada ketentuan sharīat dalam seluruh totalitas kehidupannya. ${ }^{1}$

Demikian juga kematian seseorang membawa pengaruh dan akibat hukum kepada diri, keluarga, masyarakat dan lingkungan sekitarnya. Selain itu, kematian tersebut menimbulkan kewajiban orang lain bagi dirinya (si mayit) yang

\footnotetext{
${ }^{1}$ Suparman Usman, Fiqh Mawaris Hukum Kewarisan
} Islam (Jakarta:Gaya Media Pratama, 1997) Hal 1. 
berhubungan dengan pengurusan jenazahnya (fardhu kifayah). ${ }^{2}$ Dengan kematian itu timbul pula akibat hukum lain secara otomatis, yaitu adanya hubungan ilmu hukum yang menyangkut hak para keluarganya (ahli waris) terhadap seluruh harta peninggalannya. Bahkan masyarakat dan Negara (baitul mal) pun, dalam keadaan tertentu, mempunyai hak atas peninggalan tersebut. ${ }^{3}$ Adanya kematian seseorang mengakibatkan timbulnya cabang ilmu hukum yang menyangkut bagaimana cara perpindahan atau penyelesaian harta peninggalan kepada keluarga (ahli waris) yang dikenal dengan nama hukum waris. Dalam sharīat Islām ilmu tersebut dikenal dengan nama ilmu mawārīs, fikih mawārīs, atau farāidh.

Melalui Alquran Al-Karìm, Sunnah, dan Ijtihād Sahabat bagian tiap-tiap ahli waris ditentukan dengan tujuan mewujudkan keadilan didalam Masyarakat. Bahkan dengan aturan yang sangat jelas dan sempurna Allah SWT menentukan pembagian dengan adil dan serta penuh dengan kebijaksanaan. ${ }^{4}$ Dia menetapkan hal ini dengan tujuan mewujudkan keadilan dalam kehidupan manusia, meniadakan kezaliman dalam kehidupan mereka, menutup ruang gerak para pelaku kezaliman, serta tidak membiarkan terjadinya pengaduan terhadap orang-orang yang tidak mendapatkan haknya dalam warisan. Hal ini dapat terlihat jelas dalam QS An-Nisā' ayat 7 bahwa Allah SWT dengan tegas menghilangkan bentuk kezaliman yang biasa menimpa dua jenis manusia lemah, yakni wanita dan anak-anak. ${ }^{5}$ Allah SWT

\footnotetext{
${ }^{2}$ Abdurrahmān Al Jazāri, Al Fiqh Ala Mazāhib Al
} Arbaah, Vol 1 (Beirūt : Dārul Kutub Al Ilmīyah, 2003), Hal 470.

${ }^{3}$ Ibrāhim Al Maslamī, Al Mawārịs Fìl Islam (Kairo: Muṭabiul Ahram Al Tiğarīyah, 1989) Hal 195.

4 Zamakhshari, Al Kashaf A'n Haqāiqi Gawāmidul Tanzịl, Vol 2 (Beirūt: Dārul Kutub Al Arabi, 1407 H). Hal 629.

${ }^{5}$ Al Baghowi, Al Maalimul Tanzil Fi Tafsìr Al Quran, Vol 1 (Beirūt: Dārul Ihya' Turats Al Arabi, 1420 H), Al Muhaqiq : Abdurrazak Al Mahdi, Hal 572. menyantuni keduanya dengan rahmat dan kearifanNya serta dengan penuh keadilan, yakni dengan mengembalikan hak waris mereka secara penuh.

Melihat realita hari ini, ada usaha-usaha untuk merusak tatanan hukum waris Islām yang sudah Allah tetapkan. Dengan anggapan bahwa pembagian harta warisan bagi seorang anak laki-laki sebanding dengan dua orang anak perempuan merupakan sebuah bentuk kezaliman terhadap perempuan. ${ }^{6}$ Realitas yang ditemui di tengah masyarakat berupa penyimpangan-penyimpangan terhadap hukum farāidh adalah alasan dibolehkannya melakukan modifikasi atau penyesuain terhadap ketentuan-ketentuan yang $\begin{array}{llll}\text { telah jelas digariskan oleh Alquran. } & 7 & \text { Karena }\end{array}$ terkait dengan dimensi sosiologis yang berupa struktur ekonomi masyarakat. Sebab itu kuantitas pembagian bisa dan boleh berubah dengan berdasarkan prinsip keadilan dan penyesuaian dengan dimensi sosiologis. ${ }^{8}$

Selain dari alasan di atas, bahwa ketentuan pembagian warisan di dalam Alquran termasuk pembagian formula 2:1 bagi anak laki-laki dan anak perempuan sama sekali tidak bersifat diskriminasi terhadap kaum perempuan. Dengan memberikan nilai bahwa, ketentuan anak laki-laki yang diberi warisan dua kali bagian anak perempuan tidaklah bersifat diskriminatif karena melihat konteks sosiologi dan ekonomi. Artinya, pembagian warisan dengan formula 2:1 harus dinterpretasikan kembali dengan mempertimbangkan kondisi-kondisi yang terus berubah dan kesadaran baru dikalangan perempuan. ${ }^{9}$ Bahkan, lebih parahnya wasiat lebih

\footnotetext{
${ }^{6}$ Amina Wadud Muhsin, Wanita Di Dalam Al Quran, Ter Yaziar Radiant (Bandung: Pustaka, 1994) Hal 117.

7 Munawir Sjadzali, Kontekstualisasi Ajaran Islam (IPHI/PARAMADINA,1995) Hal 90.

${ }^{8}$ Tutik Hamidah, Fiqib Perempuan Berwawasan Keadilan Gender (Malang, UIN Maliki, 2011) Hal 140

9 Asghar Ali Engineer, Hak-Hak Perempuan Dalam Islam, Terj Farid Wajidi dan Cici Farikha Assegaf (Yogyakarta: Yayasan Benteng Budaya) Hal 101-106.
} 
diutamakan dari pada waris, karena ia berpotensi untuk mewujudkan keadilan dan memiliki efektivitas dalam pemanfaatan harta dan pengembangan relasi sosial dan hubungan kekeluargaan. ${ }^{10}$

Melihat perbedaan yang mendasar dari keadilan dalam hukum waris di atas, makalah ditujukan untuk memaparkan dan menganalisa konsep adil dalam hukum waris Islām untuk menjawab argumen-argumen yang kontradiktif dalam menentukan bentuk keadilan dalam sisi teologi, ekonomi, dan sosial.

\section{KONSEP WARIS ISLAM}

Secara etimologi kata waris berasal dari bahasa arab yang berbunyi ورث برث bermakna warisan. Dalam hukum Islām dikenal adanya ketentuan-ketentuan tentang siapa yang termasuk ahli waris yang berhak menerima warisan, dan ahli waris yang tidak berhak menerima dengan adanya perpindahan kepemilikan kepada orang lain. ${ }^{11}$ Istilah fikih mawārīs dimaksudkan ilmu fikih yang mempelajari siapa-siapa ahli waris yang berhak menerima waris, siapa yang tidak berhak menerima, serta berapa banyak bagian-bagian yang diterimanya. ${ }^{12}$

Fikih mawārīs juga disebut ilmu farāidh bentuk jamak dari kata tunggal farīdah artinya ketentuan-ketentuan bagian ahli waris yang diatur secara rinci di dalam Alquran, lebih banyak membicarakan bagian ahli waris terhadap harta warisan setelah pewaris meninggal dunia. Oleh karena itu, hukum ini dinamai dengan farāidh. Al

10 Muhammad Syahrur, Metodologi Fiqh Islam Kontemporer, Terj Sahiron Syamsuddin \& Buhanuddin (Yogyakarta: eLSAQ Press, 2008) Hal 321.

H) Hal 447.

${ }^{11}$ Fatāwà Hindīyah, Vol 6, (Beirūt: Dārul Fikr, 1310

12 Ad Dasuqi, Hāshiyah Ad Dasuqi Ala Sharb Al Kabìr, Vol 4, (Beirūt: Dārul Fikr, TT) Hal 456.
Sharbinī dalam kitab Mug̉nī al Muhtāj mengatakan bahwa ilmu farāidh adalah: ${ }^{13}$

Ilmu fikih yang berkaitan dengan harta warisan, untuk mengetabui perbitungan harta waris agar sampai kepada setiap abli waris yang wajib mendapatkannya dari harta, dengan pembagian yang sesuai dengan haknya. ${ }^{14}$

Ibnū Abidīn juga mengatakan bahwa, Ilmu ushūl dari fikih dan ilmu yang menghitung hak-hak ahli waris terhadap harta warisan. ${ }^{15}$ Kata yang lazim digunakan adalah farāidh. Kata ini digunakan oleh An Nawāwī dalam fikih Minhājul Tholibīn ${ }^{16}$ dan Ibnū Qudāmah. ${ }^{17}$ Di dalam Alquran adanya ayat yang secara detail menyebutkan tentang pembagian waris menurut hukum Islām. Khusus di surat An Nisā' saja ada tiga ayat, yaitu 11, 12, dan 176. Selain itu juga ada di dalam surat Al Anfāl ayat terakhir, yaitu ayat 75 .

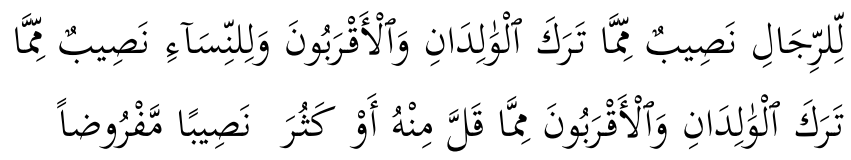

Bagi laki-laki ada hak bagian dari harta peninggalan ibubapak dan kerabatnya, dan bagi wanita ada bak bagian (pula) dari harta peninggalan ibu-bapak dan kerabatnya, baik sedikit atau banyak menurut bahagian yang telah ditetapkan. QS An Nisā':7.

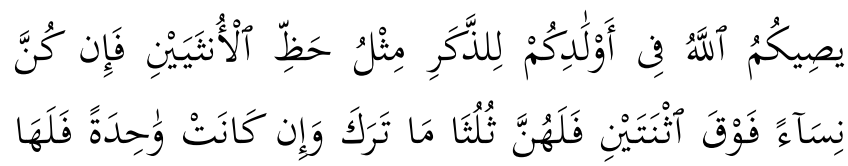

\footnotetext{
${ }^{13}$ Sharbini, Mưgnì Mubtāj Ilā Ma'rifat Ma'ānì Al Fāẓi Minhāj, Vol 4 (Beirūt : Dārul kutub Al Ilmīyah, 1994) Hal 6.

الفقه المتعلق بالإرث ومعرفة الحساب الموصل إلى معرفة ذلك ومعرفة قدر 14

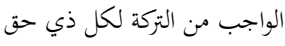

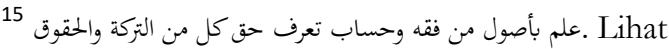

Ibnū Abidīn, Raddu Al Mukhtār Ala Düril Mukhtār, Vol 6, (Beirūt: Dārul Fikr, 2005), Hal 757.

${ }^{16}$ Nawāwī, Minhājul Ṭolibīn Fì Umdatil Muftìn Fìl

Fiqh, (Beirūt: Dārul Fikr, 2005), Hal 180

${ }^{17}$ Ibnū Qudāmah, Al Mug̀nì Wa Sharh Al Kabìr, Vol 18 (Hijr, 1995) Tahqīq : Abdullah bin Abdul Muhsin At Turkī. Hal 5.
} 


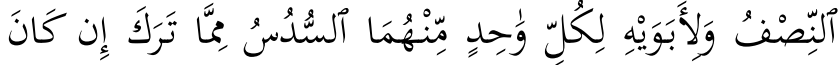

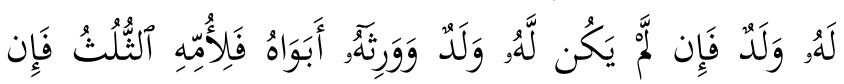

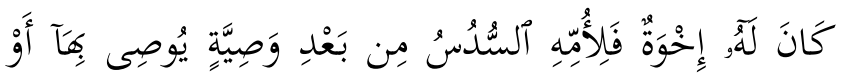

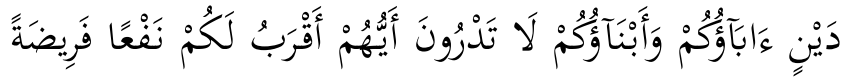

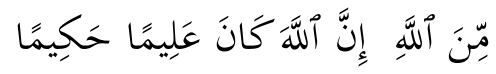

Allah mensyariatkan bagimu tentang (pembagian pusaka untuk) anak-anakmu. Yaitu: bahagian seorang anak lelaki sama dengan bahagian dua orang anak perempuan; dan jika anak itu semuanya perempuan lebib dari dua, maka bagi mereka dua pertiga dari harta yang ditingsalkan; jika anak perempuan itu seorang saja, maka ia memperoleb separo harta. Dan untuk dua orang ibubapak, bagi masing-masingnya seperenam dari harta yang ditingsalkan, jika yang meninggal itu mempunyai anak; jika orang yang meninggal tidak mempunyai anak dan ia diwarisi oleh ibu-bapaknya (saja), maka ibunya mendapat sepertiga; jika yang meninggal itu mempunyai beberapa saudara, maka ibunya mendapat seperenam. (Pembagianpembagian tersebut di atas) sesudah dipenubi wasiat yang ia buat atau (dan) sesudab dibayar utangnya. (Tentang) orang tuamu dan anak-anakmu, kamu tidak mengetabui siapa di antara mereka yang lebib dekat (banyak) manfaatnya bagimu. Ini adalah ketetapan dari Allah. Sesunggubnya Allah Maha Mengetabui lagi Maha Bijaksana. QS AnNisā’’: 11

Sedangkan dari hadīs nabi Muhammad SAW yang menunjukkan pensharīatan hukum waris diantaranya :

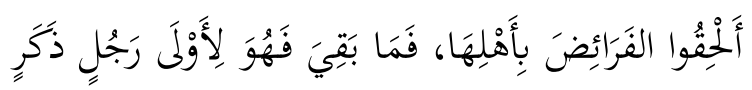

Dari Ibnü Abbas radiyallabuanbu bahwa Rasullullah $S A W$ bersabda "bagikanlah harta peninggalan (warisan) kepada yang berbak, dan apa yang tersisa menjadi bak laki-laki yang paling utama. (HR. Bukhārîi) ${ }^{18}$

Hukum waris dalam Islām atau yang lazim farāidh dalam literatul hukum Islām adalah salah satu bagian dari keseluruhan hukum Islām yang

${ }^{18}$ Al Bukhārī, Șohìh Al Bukhārì, Vol 8 (TTP : Dārul Ṭuqun Najāh, 1422) Tahqīq : Muhammad Zahir bin Nașir, Bab : Mīrāṣ, No : 6732. Hal 150 mengatur peralihan harta dari orang yang telah meninggal kepada orang yang masih hidup. Sebagian hukum agama yang terutama bersumber kepada wahyu Allah yang disampaikan oleh Nabi Muhammad SAW. Hukum kewarisan Islām mengandung berbagai asas, dan memiliki karakteristik yang berbeda dengan hukum wariswaris yang lain. Hukum waris Islām menempatkan Alquran sebagai landasan utama dan penjelasan tambahan yang diberikan oleh Nabi Muhammad SAW. Ada beberapa bentuk asas-asas yang terkandung di dalam hukum waris Islām antara lain $::^{19}$

\section{Asas Ijbari.}

Dalam hukum Islām peralihan harta dari orang yang telah meninggal kepada ahli waris berlaku dengan sendirinya. Tanpa usaha dari si mayit sebelum meninggal atau kehendak dari ahli waris. Cara peralihan ini disebut dengan ijbari. Kata ijbari secara leksikal mengandung arti paksaan (melakukan perbuatan diluar kehendak sendiri). ${ }^{20}$ Dalam istilah munakahāt terdapat istilah wali mujbir, yang bermakna bahwa seorang wanita dapat dijodohkan oleh walinya tanpa kehendak dari anak gadisnya. ${ }^{21}$ Dalam pembahasan aqidah bermakna perbuataan seorang hamba yang bukan berasal dari dirinya tetapi dari Allah SWT sebagaimana dipahami oleh sekte Jabarīyah. ${ }^{22}$

Dalam hukum waris Islām, ijbari mengandung arti peralihan harta dari seseorang yang telah meninggal kepada ahli warisnya berlaku dengan sendirinya menurut kehendak Allah SWT. Tanpa tergantung kepada kehendak dari pewaris atau permintaan dari ahli warisnya. Dan bukan juga

19 Amir Syarifuddin, Hukum Kewarisan Dalam Islam (Jakarta: kencana, 2004) Hal 17.

${ }^{20}$ Ibnū Manẓūr, Lisānul Arab, Vol 4 (Beirūt : Dārul Șodir, 1414 H) Hal 115.

21 Abū Yahya As Sunaiki, Așna Muțollib Fī Sharh Raudatul Tolib, Vol 4 (Mesir : Dārul Kitāb Al Islami, TT). Hal 247

\footnotetext{
${ }^{22}$ Ibnū Manẓūr, Lisānul Arab....Vol 4. Hal 115.
} 
diartikan sebagai pengalihan harta, karena pengalihan harta bermakna adanya usaha orang lain untuk memindahkan kepemilikan. Asas ijbari dalam hukum waris Islām dapat dilihat dalam surat An Nisā’ ayat 7 . Ayat ini menjelaskan bahwa bagi seorang laki-laki maupun perempuan ada 'Nasīb' dari harta peninggalan orang tua dan karib kerabat. Kata nasīb berarti bagian, saham, atau jatah dalam bentuk sesuatu yang diterima dari pihak lain. ${ }^{23}$ Sehingga pewaris tidak perlu menjanjikan sesuatu sebelum ia meninggal, dan ahli waris tidak perlu memintanya haknya. Karena seluruhnya sudah ditentukan langsung oleh Allah SWT.

Adanya unsur ijbari dari segi jumlah itu dapat dilihat dari kata mafrūdan yang secara etimologi berarti telah ditentukan atau telah diperhitungkan. ${ }^{24}$ Kata-kata tersebut dalam terminologi ilmu fikih berarti sesuatu yang telah Allah wajibkan kepada hambaNya. ${ }^{25}$ Ibnū Jarīr At Tabarī berkata : Dengan menggabungkan kedua kemungkinan pengertian itu, maka maksudnya ia sudah ditentukan jumlahnya dan harus dilakukan sedemikian rupa secara mengikat dan memaksa. Sehingga tidak ada hak kuasa manusia untuk dapat mengubahnya dengan cara memasukkan orang lain atau mengeluarkan orang yang berhak mendapatkan warissan. ${ }^{26}$ Adanya unsur ijbari dapat dipahami dari kelompok ahli waris sebagaimana disebutkan Allah dalam ayat 11, 12, 176 surat An Nisā’.

Asas Bilateral

23 Abū Husain, Mu’jam Maqàyìs Al Lugioh, Vol 3, (Beirūt : Dārul Fikr, 1979) Muhaqīq :Abdul Salām Harun. Hal 111.

${ }^{24}$ Ibnū Jarīr At Ṭabarī, Jämiul Bayān Fì Ta'mūl Ayyi Al Qurān, Vol 7, (Beirūt: Muassasah Risālah, 2000 M) Muhaqīq : Ahmad Muhammad Shakir. Hal 599.

${ }^{25}$ Ibnū Manzuūr, Lisānul Arab......Vol 4. Hal 115.

${ }^{26}$ Jasșas, Abkāmul Qurān, Vol 2, (Beirūt : Dārul Ihya Turats Al Arobi, 1405) Muhaqīq : Muhammad Șadiq Al Qamhawi. Hal 367.
Asas bilateral dalam kewarisan mengandung arti bahwa harta warisan beralih kepada atau melalui dua arah. Hal ini bahwa setiap orang menerima hak kewarisan dari kedua pihak garis kerabat, yaitu pihak kerabat garis keturunan laki-laki dan pihak kerabat garis keturunan perempuan. Asas bilateral dapat secar nyata dilihat dalam firman Allah SWT dalam surat An-Nisa ayat, 7, 11, 12 dan 176. Dalam ayat 7 dijelaskan bahwa seorang lakilaki berhak mendapatkan warisan dari pihak ayahnya dan juga dari pihak ibunya. Begitu pula seorang perempuan berhak menerima harta warisan dari pihak ayahnya dan juga dari pihak ibunya. Ayat tersebut merupakan dasar bagi kewarisan bilateral itu. Secara terinci asas bilateral itu dapat dipahami dalam ayat-ayat selanjutnya. ${ }^{27}$

Dari tiga ayat dikemukan di atas terlihat jelas bahwa kewarisan itu beralih kebawah (anakanak), keatas (ayah dan ibu) dan kesamping (saudara-saudara) dari kedua belah pihak garis keluarga, yaitu laki-laki dan perempuan dan menerima warisan dari dua garis keluarga yaitu dari garis laki-laki dan garis perempuan. Inilah yang dinamakan kewarisan secara bilateral.

\section{Asas Individu.}

Hukum Islām mengajarkan asas kewarisan secara individual, dengan arti bahwa harta warisan dapat dibagi secara perorangan. Masing-masing ahli waris menerima bagiannya secara tersendiri, tanpa terikat dengan ahli waris yang lain. Keseluruhan harta warisan dinyatakan dalam nilai tertentu yang mungkin dibagi-bagi; kemudian jumlah tersebut dibagikan kepada setiap ahli waris yang berhak menurut kadar bagian masing-masing. Setiap ahli waris berhak atas bagian yang didapatnya tanpa tergantung dan terikat dengan ahli waris yang lain. Hal didasarkan kepada ketentuan bahwa setiap insan sebagai pribadi mempunyai kemampuan

${ }^{27}$ Wahbah Zuhailī, Tafsìr Wasit, Vol 1, (Damaskus: Dārul Fikr, 1422 H). P 288. 
untuk menerima hak dan menjalankan kewajiban, yang di dalam ushūl fikih disebut Ablìyat $A l$ Wujüb. ${ }^{28}$ Dalam pengertian ini setiap ahli waris berhak menuntut secara sendiri-sendiri harta warisan itu dan berhak pula untuk tidak berbuat demikian.

Pembagian secara individu ini adalah ketentuan yang mengikat dan wajib dijalankan oleh setiap muslim dengan sanksi berat di akhirat bagi yang melanggarnya sebagaiamana yang dinyatakan Allah dalam surat An Nisā' ayat 13 dan 14. Bila telah terlaksana pembagian secara terpisah untuk setiap ahli waris, maka untuk seterusnya ahli waris memiliki hak penuh untuk menggunakan harta tersebut. Walaupun dibalik kebebasan menggunakan harta tersebut terdapat ketentuan lain yang dalam kaidah ushūl fikih disebut Ahlīyat Al Adā'. 29

Menghilangkan bentuk individualnya dengan jalan mencampuradukkan harta warisan tanpa perhitungan dan sengaja menjadikan hak kewarisan tanpa perhitungan dan dengan sengaja menjadikan hak kewarisan itu bersifat kolektif berarti menyalahi ketentuan yang disebut di atas. Hal tersebut akan mengakibatkan pelakunya terkena sanksi sebagaimana disebutkan di akhir ayat 2 surat An Nisā' yaitu perilakunya dosa besar. Dari penjelasan diatas dapat disimpulkan bahwa bentuk kewarisan koleftif tidak sesuai dengan ajaran Islām; karena cara tersebut dikhawatirkan akan memakan hak anak yatim yang terdapat dalam harta tersebut. $^{30}$

\section{Asas Keadilan Yang Berimbang}

Kata adil merupakan kata bahasa Indonesia yang berasal dari kata al-adlu. Di dalam Alquran kata al adlu disebutkan lebih dari 28 kali. Sebagian

${ }^{28}$ Sarkhashī, Ușūl Sarkhashī, Vol 2, (Beirūt: Dārul Ma'rif, T'T). Hal 333.

${ }^{29}$ Muhammad Abū Zahrah, Ușūl Fiqh (Dārul Fikr Al Arabī, T'T) Hal 333

${ }^{30}$ Ibid. Hal 333 diantaranya diturunkan Allah dalam bentuk kalimat perintah dan sebagian dalam bentuk kalimat berita. Kata al adlu itu dikemukan dalam konteks yang berbeda dan arah yang berbeda pula ; sehingga akan memberikan definisi yang berbeda sesuai dengan konteks dan tujuan penggunanya. ${ }^{31}$ Untuk lebih jelasnya keadilan berimbang dalam waris hukum Islām akan dibahas pada bab "Keadilan Universal Dalam Hukum Waris Islām”.

Secara istilah keadilan diartikan bahwa menempatkan sesuatu pada tempatnya, waktunya, kedudukannya, kadarnya tanpa adanya sikap mengurangi dan melebihi. ${ }^{32}$ Menurut Al Jurjān̄̄ keadilan adalah istiqomah dalam jalan kebenaran dan meninggalkan segala bentuk yang dapat merusak agama. ${ }^{33}$ Abdurrahman Sa'dī menyebutkan, "Keadilan Allah itu mencakup di dalam hak Allah dan HambaNya, keadilan yang menunaikan hak-hak secara sempurna dengan cara mengerjakan kewajiban Allah atas HambaNya dalam persoalan hak-hak terhadap harta, jiwa. ${ }^{34}$ Menurut Wahbah Zuhailī adil adalah mengamalkan setiap kewajiban baik itu dari aqidah dan shariat, dan berinteraksi dengan manusia dengan memenuhi amanah, tidak berbuat zhalim, berlaku seimbang, dan bersikap benar. ${ }^{35}$

Keadilan dalam hukum Islam digantungkan pada keadilan yang telah ditentukan oleh Allah SWT, karena tidak mungkin manusia mengetahui

\footnotetext{
31 Amir Syarifuddin, Hukum Kewarisan Dalam Islam...Hal 19.

32 Abū Us̉man Al Jāhiz, Tahı̃ib Al Akblāk (Iskandarīya : Dārul Șahābah Li Turaś, 1989 ) Hal 28.

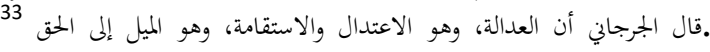

Lihat. Al Jurjān̄in, At Ta'rî́āt (Beirūt : Dārul Kutub Al Ilmīyah, 1983) Hal 147.

أداء الحقوق كاملة موفرة بأن يؤدي العبد ما أوجب الله عليه من الحقوق المالية 34 قال السعدي أن العدل والبدنية Karim Ar Rabmān Fì Tafsìr Kalàmil Mannān (Beirūt : Muassasah Risalāh 2000 M) Hal 447.

قال وهبة الزهيلي العدل: هو فعل كل مفروض، من عقائد وشرائع، وسير مع 35 lihat Wahbah Zuhaili, Tafsir W asit, Vol 2, Hal 1295.
} 
keadilan itu secara benar dan tepat. Dalam hukum Islam, keimanan mendahului pengertian, karena telah ditetapkan bahwa segala yang ditetapkan Allah SWT pasti adil. Sehingga adil dalam perkara waris adalah menjalankan perintah Allah dalam perkara warisan dengan cara membaginya sesuai dengan aturan yang sesuai dengan Alquran dan Sunnah.

\section{Asas Semata Akibat Kematian}

Hukum Islām menetapkan bahwa peralihan harta seseorang kepada orang lain dengan menggunakan istilah kewarisan hanya berlaku setelah yang mempunyai harta meninggal dunia. Asas ini berarti bahwa harta seseorang tidak dapat beralih kepada orang lain dengan nama waris selama yang mempunyai harta masih hidup. Juga berarti bahwa segala bentuk peralihan harta seseorang yang masih hidup baik secara langsung, maupun terlaksana setelah mati, tidak termasuk kedalam istilah waris menurut hukum Islām. Dengan demikian hukum waris dalam Islām hanya mengenal satu bentuk hukum waris yaitu waris akibat kematian semata. ${ }^{36}$

Asas waris dalam Islām akibat kematian ini mempunyai kaitan erat dengan asas ijbari yang sebelumnnya dibahas. Pada hakikatnya, seseorang yang telah memenuhi syarat sebagai subyek hukum dapat menggunakan hartanya secara penuh untuk memenuhi keinginan dan kebutuhan sepanjang hayatnya. Namun, setelah meninggal dunia, ia tidak lagi memiliki kebebasan tersebut. Kalau pun ada, maka pengaturan untuk tujuan penggunaan setelah kematian terbatas dalam koridor maksimal sepertiga dari hartanya, dilakukan setelah kematiannya, dan tidak disebut dengan istilah waris. ${ }^{37}$ Dengan

\footnotetext{
${ }^{36}$ Șolih Fauzān, Tahqīqāt Al Mardìyah Fì Mabāhìs Al Fardìyah (Riyāụ: Maktabah Ma'rif, 1986) Hal 31.

37 Wasiat adalah hibah seseorang kepada orang lain dalam bentuk harta, barang yang diserahkan kepada si penerima setelah orang yang memberi wasiat meninggal. Lihat Sayyid Sābiq, Fiqh As Sunnah, Vol 3, (Kairo: Al Fath Lil I'lāmi Al Arabi, TT) Hal 284.
}

demikian, ini merupakan karakteristik asas waris dalam Islām dan menjadi pembeda antara hukum waris yang lainnya.

\section{SEBAB PEWARISAN DALAM ISLAM}

Menurut jumhur ulama bahwa sebab-sebab seseorang mewarisi harta seseorang yang meninggal dunia ada 3 macam; yaitu kekerabatan, pernikahan, dan wala' ${ }^{38}$ Para ulama Malikiyah dan Shafiyah memberi tambahan sebab, untuk memperoleh hak waris yaitu jalur keIslāman (hubungan Islām). ${ }^{39}$ Pertama; pernikahan yang sah menurut shara' merupakan suatu ikatan yang sentosa untuk mempertemukan seorang laki-laki dengan wanita, selama ikatan pernikahan itu masih abadi. Apabila diantara keduanya ada yang meninggal dunia pada waktu perkawinannya masih utuh atau dianggap utuh (talak raj'i yang masih dalam iddah), maka pernikahan antara suami dan istri. Dan keduanya akan mendapatkan furādhah muqaddarah yang telah ditetapkan oleh Shara' yakni $1 / 2,1 / 4$, atau 1/8. ${ }^{40}$ Sebagaimana firman Allah Surat an-Nisa: "dan bagimu (suami) seperdua dari harta yang ditinggalkean oleb istri-istrimu, jika mereka tidak mempunyai anak".

Kedua; Kekerabatan ialah hubungan nasab antara orang yang mewariskan dengan orang yang mewarisi yang disebabkan oleh kelahiran. Pertalian hubungan darah ini merupakan sebab seseorang memperoleh hak mewarisi yang terkuat, dikarenakan kekerabatan itu termasuk unsur yang tidak dapat dihilangkan. Kekerabatan yang mendapatkan harta waris seperti, pertalian ushūl yaitu pertalian lurus keatas dari si mayyit seperti ibu, nenek, ayah, kakek, dan seterusnya. Pertalian furū', yaitu pertalian lurus kebawah anak dari mayyit, cucu, cicit dan seterusnya. Pertalian hawashi, yaitu

38 Maryam Ahmad Ad Daghistani, Al Mawāris Fi Shariah Al Islamìab Ala Mazāhib Al Arbaab (Kairo: Universitas Al Azhar, 2001) Hal 15

39 Ibid.

${ }^{40}$ Sayyid Sābiq, Fiqh Sunnah, Vol 3, (Kairo: Al Fath Lil I'lāmi Al Arabi, TT) P 298. 
pertalian menyamping dari sisi si mayyit seperti saudara, paman, keponakan, dan seterusnya. ${ }^{41}$

Ketiga; Wala' adalah kekerabatan menurut hukum yang disebabkan karena membebaskan budak. Apabila seorang pemilik budak telah membebaskan budanya, berarti ia telah merubah status hukum orang yang semula tidak termasuk memiliki kepada memiliki dan mengelola harta bendanya sendiri. ${ }^{42}$ Sebagaimana disabdakanNabi Muhammad SAW "Sesungguhnya hak wala' itu bagi orang yang memerdekakan” (HR. Al Hakim). ${ }^{43}$

\section{PENGHALANG WARIS DALAM ISLAM}

Faktor-faktor yang dapat menghalangi waris ialah tindakan atau hal-hal yang dapat menggugurkan hak seseorang (ahli waris) untuk mendapatkan warisan beserta adanya sebab-sebab dan syarat-syarat mewarisi. Hal-hal yang yang dapat menghalangi waris dalam Islām yang disepakati para fuqāha' ada 3 macam yaitu, pembunuhan, perbedaan agama dan perbudakan. Status budak tidak bisa mewarisi dan tidak juga menjadi ahli waris. Karena statusnya masih milik tuannya secara mutlak. Sebagaimana firman Allah dalam Surat AnNisa "Allah telah membuat perumpamaan seseorang budak yang tidak dapat bertindak apa-apa".

Faktor yang kedua adalah pembunuhan. Jumhur fuqāha' berpendapat, bahwa pembunuhan dapat menghalangi seseorang menjadi ahli waris. Begitu juga penganiayaan yang mengakibatkan terbunuhnya seseorang. Dasar hukum yang menghalangi terhadap si pembunuh "Barang siapa membunub korban, maka ia tidak dapat mewarisinya, walaupun tidak punya abli waris selain dirinya, baik korban itu bapaknya atau anaknya, maka bagi pembunub tidak berhak mewarisinya (HR. Ahmad)"

\footnotetext{
${ }^{41}$ Ibid. Hal 298.

42 Maryam Ahmad Ad Dağhistani, Al Mawāi ï Fì Shariah Al Islamìyah Ala Mazuăhib Al Arbaah..Hal 12.

${ }^{43}$ Musnad Abū Dāwnd, Vol 3, (Mesir: Dārul Hijr 1999 M) Muhaqīq : Abdul Muhsin. Hal 404
}

Faktor yang ketiga adalah berbedaan agama. Dasar hukum berbedaan agama sebagai penghalang seseorang dapat mewarisi adalah hadīs Nabi SAW "Orang Isläm tidak dapat mewarisi barta orang kafir dan orang kafir tidak dapat mewarisi harta orang muslim" (HR. Bukhārī dan Muslim). Sedangkan orang yang murtad, dia tidak dapat mewarisi harta peninggalan keluarganya, baik keluarganya orang Islām, orang kafir maupun murtad. Jika keadaanya demikian, maka hartanya akan diwarisi oleh Baitul Māl. ${ }^{44}$

\section{KONSEP ADIL DALAM WARIS ISLAM}

Keadilan Berimbang Dalam Hukum Waris Isläm

Keadilan dalam hukum waris erat kaitannya dengan hak dan kewajiban dan keseimbangan antara yang diperoleh dengan keperluan dan kegunaan. Atas dasar pengertian tesebut terlihat asas keadilan dalam pembagian harta warisan dalam hukum Islām. Secara mendasar dapat dikatakan bahwa perbedaan gender tidak menentukan hak kewarisan dalam Islām. Artinya, sebagaimana pria, wanita pun mendapatkan hak yang sama kuat untuk mendapatkan warisan. Hal ini secara jelas disebutkan dalam surat An Nisā' ayat 7 yang menyamakan kedudukan laki-laki dan perempuan dalam hak mendapatkan warisan. Pada ayat 11-12, dan 176 surat An Nisā' secara rinci diterangkan kesamaan kekuatan hak menerima warisan antara laki-laki dan perempuan, ayah dan ibu (ayat 11), suami dan istri (ayat 12), saudara laki-laki dan perempuan (ayat 12 dan 176).

Tentang jumlah bagian yang didapat oleh laki-laki dan perempuan terdapat tiga bentuk :

Pertama, Laki-laki mendapat jumlah yang sama banyak dengan perempuan:seperti ibu dan ayah (sama-sama mendapatkan 1/6) dalam keadaan pewaris meninggalkan anak kandung. Begitu pula saudara laki-laki dan saudara perempuan sama-sama mendapatkan 1/6 (dalam kasus pewaris adalah seorang yang tidak memiliki ahli waris langsung).

${ }^{44}$ Ibrāhīm Al Maslami, al mawāris̀ fì islam...Hal 195. 
Kedua Laki-laki memperoleh bagian lebih banyak atau dua kali lipat dari yang didapat oleh perempuan dalam kasus yang sama yaitu anak lakilaki dengan anak perempuan. Dalam kasus yang terpisah duda mendapat dua kali bagian yang diperoleh oleh janda yaitu $1 / 2$ berbanding $1 / 4$ bila pewaris tidak ada meninggalkan anak; dan $1 / 4$ banding $1 / 8$ bila pewaris meninggalkan anak.

Ketiga perempuan lebih besar dari pada laki-laki dan keadaan yang perempuan mewarisi laki-laki tidak mewarisi.

Ditinjau dari segi jumlah bagian yang diperoleh saat menerima hak, memang terdapat ketidaksamaan. Akan tetapi hal tersebut bukan berarti tidak adil, karena keadilan dalam pandangan Islām tidak hanya diukur dengan jumlah yang didapat saat menerima hak waris tetapi juga dikaitkan kepada kegunaan dan kebutuhan. Secara umum, dapat dikatakan pria membutuhkan lebih banyak materi dibandingkan wanita. Hal tersebut dikarenakan pria dalam ajaran Islām memikul kewajiban ganda yaitu untuk dirinya sendiri dan terhadap keluarganya termasuk wanita sebagaimana Allah jelaskan didalam Surat An Nisā̄ ayat 34 "Laki-laki adalah pembimbing bagi perempuan karena Allab telah melebibkan sebagian mereka atas sebagian yang lain dan karena mereka memberi nafkah dengan harta mereka."

Bila dihubungkan jumlah yang diterima dengan kewajiban dan tanggungjawab seperti disebutkan di atas, maka akan terlihat bahwa kadar manfaat yang akan dirasakan pria sama dengan apa yang dirasakan oleh pihak wanita. Meskipun ada pada mulanya pria menerima dua kali lipat dari perempuan, namun sebagian dari yang diterima akan diberikannya kedapa wanita dalam kapasitasnya sebagai pembimbing yang bertangungjawab. Bagi seorang laki-laki, tanggung jawab utamanya adalah istri dan anak-anaknya. Ini merupakan kewajiban dari Allah yang harus dipikul QS Al Baqarah ayat 233 “...kewajiban ayah memberi makan dan pakaian untuk para ibu dan anak-anak secara makruf'. Terhadap kerabat lain, tanggungjawab seseorang hanya bersifat tambahan dan bukan utama. Tanggunjawab itu dipikulnya bila ia mampu berbuat demikian di satu pihak, dan dipihak lain kerabat itu membutuhkan bantuan. Tanggung jawab terhadap kerabat ini disebutkan Allah dalam QS Al Baqarah 215 "Mereka bertanya kepadamu tentang apa yang mereka nafkabkan;jawablab:apa saja barta yang kamu nafkabkan bendaklah diberikan kepada ibu-bapak dan karib kerabat."

Persoalan yang juga harus diperhatikan bahwa waris dalam Islām melihat hubungan kekerabatan, semakin dekat hubungan semakin berhak untuk mendapatkan warisan. Bukan berdasarkan status sosial atau ekonomi.

Jika hukum waris disandarkan kepada realita sosial, akan berakibat tunduknya ajaran Islām kepada realita sosial yang senantiasa berubah. Dan hukum waris Islām pada akhirnya berubah dari agama wahyu menjadi agama budaya yang melihat status sosial masyarakat. Para ulama telah menyatakan bahwa pembagian warisan harus tetap merujuk kepada Alquran dan Sunnah. Inilah bentuk keadilan hakiki dalam pandangan Islām dalam persolan warisan, yaitu keadilan yang berimbang dan bukan keadilan yang merata.

\section{Hikmab Dibalik Ketentuan Waris Isläm 2:1}

Perlu untuk diketahui bahwa Allah SWT mempunyai hikmah yang agung dalam melebihkan anak laki-laki dari pada anak perempuan tentang pembagian warisan. Hikmah Allah ini tidak diketahui oleh orang-orang menyerukan persamaan gender dalam warisan sebagaimana yang telah dijelaskan dalam Muqoddimah. Shanqị̄̂i menerangkan bahwa termasuk petunjuk Alquran kepada jalan yang lebih lurus adalah melebihkan anak laki-laki dari pada anak perempuan dalam hal warisan. Tidak diragukan lagi bahwa jalan yang paling lurus dan adil adalah dengan melebihkan anak laki-laki dari anak perempuan dalam hal 
warisan. Karena laki-laki senantiasa dituntut untuk memberi nafkah kepada wanita yang menjadi tanggungannya, memberi mahar buat perempuan, dan membelanjakan hartanya untuk berbagai keperluan hidup mereka. Dengan begitu, melebihkan bagian untuk menutupi tanggung jawabnya merupakan hikmah yang nyata.

Maka, jika wanita memperoleh bagian yang sama dengan saudara laki-laki dalam warisan, dengan keistimewaan yang dimilikinya ini, pada hakikatnya hilanglah persamaan itu. Bahkan bertambahlah hak wanita dan berkuranglah hak yang dimiliki laki-laki, sebab wanita sudah memiliki hak waris sekaligus hak memberi nafkah. Berbeda dengan laki-laki, ia tidak mempunyai hak selain hak yang sama dengan wanita dalam warisan, jika keduanya memiliki kedudukan yang sama. Maka jika ada yang berkata "Yang benar adalah wanita harus menafkahi laki-laki dan menyerahkan mahar kepada suaminya kemudian menyainginya dalam warisan". Kalau benar seperti ini, dan menjadi prinsip dasar yang harus diamalkan, tentu gugurlah pernikahan mayoritas wanita disebabkan kemiskinan mereka, karena mereka tidak memiliki sesuatu yang harus diberikan sebagai mahar dan nafkah.

\section{Fleksibelitas Hukum Waris Isläm}

Tanāzul dalam warisan sangat dikenal dalam ilmu fikih, disaat salah satu ahli waris tidak menerima harta waris setelah ditentukan bagian sesuai dengan ketentuan Islām. karena melihat adanya ahli waris yang lain lebih membutuhkan harta. Sehingga status harta tersebut adalah hibah, hal disebabkan karena adanya kebutuhan. Dengan adanya tanāzul menyebabkan hukum waris menjadi fleksibel ditengah-tengah masyarakat. Tentu hal ini diperbolehkan disaat setelah adanya penentuan bagian waris yang sesuai dengan Islām. Tanāzul seorang istri dari hak waris demi kemaslahatan shar'i ada dua bentuk: Pertama, dia mengundurkan diri dari hak waris tanpa pergantian (imbalan).
Misalnya, dia menyerahkan kepada suaminya untuk anak-anaknya, karena melihat kebutuhan mereka. Kedua, dia mengundurkan diri dari hak waris dengan imbalan (pergantian).

Masalah ini diperbolehkan dan masybur di dalam pembahasan buku fikih, selama dilakukan dengan suka rela (ridha). Istri mundur dari bagiannya dalam warisan dengan imbalan sejumlah harta, mungkin dari warisan itu atau dari yang lain. Abdurrazaq, Saīd bin Manșūr,dan Baihaqī dengan sanad șahīh, bahwa istri Abdurrahman bin Auf berdamai atas bagiannya $1 / 4$ menjadi $1 / 8$ dengan ganti 80.000 dirham. Kisah ini terjadi di antara jamaah para sahabat, dan tidak diketahui ada yang mengingkarinya.

\section{Konsep Pembagian Waris Isläm Untuk Perempuan}

Sharīat Islām mengatur perkara warisan dengan adil. Jika ada yang menyebutkan pembagian warisan tidak adil disebabkan karena perempuan mendapatkan lebih sedikit dari laki-laki ini tidaklah benar. Perlu untuk dipahami lebih dalam setelah kita mengkaji sebab kenapa laki-laki lebih banyak mendapat bagian dari pada perempuan. Kita akan mendapatkan bahwa bagian perempuan tidak selalu yang lebih sedikit dari bagian waris laki-laki. Ada kondisi-kondisi tertentu yang menyebabkan pembagian warisan bagi perempuan sama besarnya dengan bagian waris laki-laki, bahkan dalam kondisi tertentu, bagian waris perempuan bisa lebih banyak dibandingkan dengan bagian laki-laki.

Adapun kasus perempuan yang mendapatkan bagian lebih sedikit dibandingkan laki-laki hanya ada 4 kasus saja yaitu;

Pertama, apabila anak perempuan dan lakilaki, maka anak perempuan mendapatkan setengah dari bagian laki-laki. Kedua, apabila terdapat ayah dan ibu pewaris, sedangkan dia tidak mempunyai keturunan, dan juga tidak mempunyai istri atau suami maka ibu mendapatkan $1 / 3$, dan sisanya adalah bagian ayah. Ketiga, apabila terdapat saudara 
dan saudari kandung dari pewaris, dan dia tidak memiliki anak dan orang tua. Maka saudari kandung mendapatkan $1 / 3$ dan sisanya $2 / 3$ untuk saudara laki-laki kandung. Sebagaimana firman Allah SWT dalam surat An Nisā' ayat 176. Keempat, apabila terdapat saudara laki-laki sebapak, dan saudari perempuan sebapak, dan jika pewaris tidak memiliki saudara kandung, anak, dan orang tuan, maka saudara perempuan $1 / 3$ dan sisanya $2 / 3$ untuk saudara laki-laki sebapaknya.

Adapun bagian perempuan lebih banyak dari laki-laki, dan bukti konsep pembagian waris Islām lebih menyayangi perempuan. Hal ini setidaknya bisa dilihat dari dua sisi: Sisi perrtama, lebih banyaknya kaum perempuan dari pada lakilaki dalam posisi așhābul furūd. Dalam Islām ahli waris dikelompokan menjadi dua Așhäbul furūd dan Ashabah . Dalam Alquran disebutkan bahwa aṣhäbul furūd berjumlah 12 orang. 8 orang dari perempuan yaitu: ibu, nenek, istri, anak perempuan, cucu perempuan, saudari kandung, saudari sebapak, dan saudari seibu. 4 dari laki-laki yaitu, ayah, kakek, suami, dan saudara laki-laki seibu. Bagian terbesar dalam warisan adalah $2 / 3$, dan ahli waris yang mendapatkan jatah $2 / 3$ itu semuanya perempuan, yaitu 2 anak perempuan atau lebih, 2 saudari kandung atau lebih, 2 saudari sebapak atau lebih, 2 saudari seibu.

Ini merupakan bukti bahwa Islām tidak mendiskriminasi perempuan, karena Islām telah menetapkan banyak aṣhābul furü dari perempuan yang mana hak aṣhābul furūẹ itu harus didahulukan dengan ashabah.

Sisi kedua, kasus-kasus yang terdapat dalam warisan Islām justru memperlihatkan bahwa kaum perempuan lebih banyak punya potensi mendapatkan warisan lebih besar dari laki-laki.

Apabila si mayyit meninggalkan suami, bapak, ibu, seorang anak perempuan, dan cucu perempuan. Harta yang ditinggalkan misalkan 195 dinar. Maka cucu perempuan akan mendapatkan bagian 1/6 dari harta warisan yaitu sebanyak 26 dinar. Namun seandainya si mayyit meninggalkan cucu laki-laki dan tidak meninggalkan cucu perempuan, maka ia tidak mendapatkan bagian sama sekali.

Apabila Si Mayyit meninggalkan suami, saudari kandung, dan saudari sebapak, maka saudari perempuan sebapak akan mendapatkan 1/6 dari harta yang ditinggalkan. Namun apabila si Mayyit meninggalkan saudara laki-laki sebapak dan tidak meniggalkan saudari perempuan sebapak, ia tidak akan mendapatkan harta warisan, sebab separoh harta untuk suami dan separuhnya lagi untuk saudari perempuan kandung, sedangkan sisanya untuk saudara laki-laki sebapak. Namun ia tidak mendapatkannya karena sisanya tidak ada.

\section{Keadilan Universal Dalam Hukum Waris Isläm.}

Setelah membahas keadilan hukum waris Islām dari sisi teologi. yang mana harus meyakini bahwa Allah SWT menetapkan syarīat waris mengandung keadilan bagi hambaNya. Sehingga tidak ada anggapan bahwa hukum waris Islām tidak berlaku adil dan mengarah kepada diskriminasi terhadap perempuan, karena keadilan tersebut telah kita buktikan dari sisi maslahat dalam praktek pembagian waris Islām. Di samping itu perlu kiranya untuk membahas keadilan waris Islām yang ditinjau dari sisi ekonomi dan sosial.

Sistem waris dalam Islām memiliki peran yang sangat signifikan dalam perpindahan kepemilikan besar yang bermakna distribusi secara adil terhadap pendapatan dan kekayaan anggota keluarga yang memiliki hak waris. Hal ini juga menunjukkan bahwa keadilan hukum sistem waris Islām yang memperhatikan tingkat kebutuhan kepada harta dengan membagi jatah laki-laki dan perempuan dengan perbandingan dua banding satu, disebabkan kaum laki-laki sebagai penanggungjawab seluruh nafkah atas perempuan.

Sedangkan menurut Rāzaq Makhur Al Garawi beliau menguraikan beberapa poin dalam 
sistem waris Islām yang juga menjelaskan keterangan tentang sisi akutansi dalam waris. Pensharīatan dalam sharīat selalu memiliki Maqāīdu Shariah, prinsip dan bersifat perintah. Perintah dalam sharīat Islām selalu tunduk pada prinsip, dan prinsip selalu ada dibawah Maqāīdu Sharīah atau tujuan yang dihendaki shariat. Dalam hal ini, ia mengambil contoh soal keadilan dan keseimbangan sebagai kaidah sharīat Islām, terutama menyangkut hukum waris yang adil. Keadilan dalam system waris diulas dengan mengurai beberapa sisi, antara lain, persamaan mutlak adalah kezaliman. Persamaan harus dibedakan dengan keadilan. Jika dalam satu kelas pendidikan seorang guru menyamaratakan nilai untuk seluruh murid, dengan tidak membedakan antara murid yang lulus dan murid yang tidak lulus, antara yang patuh dan yang tidak patuh, maka ini adalah kezaliman. dalam sistem waris, kaitannya dengan ekonomi keluarga serta masyarakat, maka pembagian dua banding satu untuk laki-laki dan perempuan adalah kezaliman.

Dengan sistem waris Islām, sama sekali tidak membiarkan kekayaan dimiliki oleh satu orang, dan karenanya kekayaan itu didistribusikan kepada ahli waris, dan mehapuskan sikap induvidualisme dalam soal harta. Ini artinya, sistem waris mempermudah peredaran harta dengan pembagian harta kekayaan dan melarang harta terkonsentrasi pada beberapa orang terbatas. Sehingga dengan sistem waris Islām harta menjadi luas pemanfaatannya dan dapat memelihara bangunan ekonomi Islām dari bentuk penimbunan harta.

Jika penimbunan harta kekayaan yang belebihan di tangan orang kaya: adanya kekayaan berlebihan yang ada di tangan golongan ekonomi yang kuat ini akan mengantarkan munculnya penyelewengan dan dosa.

\section{Keadilan Sosial Dalam Hukum Waris Isläm}

Islām mendukung adanya hak bagi anggota keluarga, dan menyerukan lewat Alquran dan Sunnah, agar mereka terhadap sesama anggota yang lain, saling berbuat baik, menghidupkan hubungan keluarga dan saling berbuat kebajikan. Allah mengancam dengan azab yang pedih bagi siapa yang memutuskan keluarga atau berbuat aniaya terhadap keluarganya. Dalam surat an Nisā' ayat 1 "Dan takutlah kepada Allah yang kami tujukan permintaan kepadaNya, dan peliharalah keluarga, karena sesunggubnya Allah itu pengawas atas kamu".

Dan Rasulullah SAW juga bersabda :

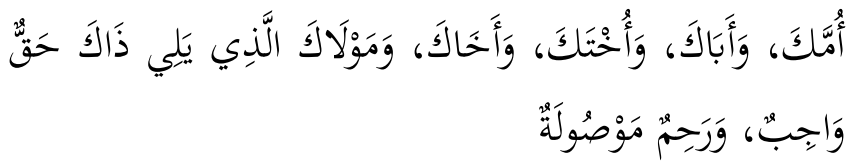

Berbuat baik kepadamu, ayahmu, saudaramu perempuan, saudaramu laki-laki, dan kerabatmu sesudah mereka, adalah satu ketentuan yang wajib dan keluarga yang harus disambung. (HR. Abu Dawud)

Ayat dan hadìs tersebut menunjukkan bahwa anggota keluarga terhadap keluarganya mempunyai hak yang lebih banyak dari pada terhadap orang lain, karena adanya ikatan karena adanya ikatan nasab dan keluarga. Kewajiban tersebut berarti pemberian bantuan dan nafkah kepada keluarga yang tidak mampu. Kalau seorang anggota keluaga dapat mewaris keluarganya sesudah meninggal dunia sehingga menjadi cukup, adillah bila ia diwajibkan memberi nafkah kepadanya pada saat ia tidak mampu, sehingga ia tidak terlantar.

Gambaran adanya saling menjamin antara keluarga dalam Islām terlihat dalam bentuk warisan harta yang secara terperinci dikemukan dalan Alquran. Antara lain gambaran jaminan yang ada pada seseorang terhadap keluarganya, dan antara generasi yang terdahulu secara berturut yang diatur oleh Islām, lebih dari sekedar sebagai cara agar supaya kekayaan itu tidak tertimbun dalam membahayakan kepada masyarakat. Tidak ada artinya menyambung keluarga (silaturrahim) tanpa memberi nafkah kepada orang yang membutuhkan. 
Dengan adanya hukum waris Islām dan konsep nafkah, sehingga orang-orang yang mendapatkan kelebihan nikmat yang Allah berikan wajib untuk memberi nafkah kepada keluarganya yang tidak mampu. Karena itu, termasuk hak setiap orang miskin yang muslim untuk mengajukan tuntutan nafkah kepada keluarganya yang Allah berikan kelebihan harta. Ini berarti Islām telah meletakkan modal pertama bagi terciptanya jaminan sosial.

\section{PENUTUP}

Dari pembahasan keadilan universal dalam hukum waris Islām dapat kita simpulkan bahwa salah satu asas terpenting dalam hukum waris dalam Islām adalah Ijbari, yang mana peralihan harta dari seseorang yang telah meninggal kepada ahli warisnya berlaku dengan sendirinya menurut kehendak Allah SWT. Tanpa tergantung kepada kehendak dari pewaris atau permintaan dari ahli warisnya. Dan bukan juga diartikan sebagai pengalihan harta, karena pengalihan harta bermakna adanya usaha orang lain untuk memindahkan kepemilikan.

Makna keadilan dalam hukum waris Islām harus mengikuti ketentunan Allah SWT bukan pembagian yang sama rata. Dibalik pembagian waris dalam Islām mengandung keadilan yang bersifat Universal ditinjau dari sisi teologi, ekonomi, sosial.

Dari sisi teologi dapat dirasakan disaat meyakini bahwa Allah SWT menetapkan shariat waris mengandung keadilan bagi hambaNya. Sehingga tidak ada anggapan bahwa hukum waris Islām tidak berlaku adil dan mengarah kepada diskriminasi terhadap perempuan, karena keadilan tersebut telah kita buktikan dari sisi maslahat dalam praktek pembagian waris Islām.

Sistem waris Islām mempermudah peredaran harta dengan pembagian harta kekayaan dan melarang harta terkonsentrasi pada beberapa orang terbatas. Sehingga dengan system waris Islām harta menjadi luas pemanfaatannya dan dapat memelihara bangunan ekonomi Islām dari bentuk penimbunan harta.

Hukum waris dan konsep nafkah dalam Islām tidak dapat dipisahkan sehingga orang-orang yang mendapatkan kelebihan nikmat yang Allah berikan berupaharta warisan wajib untuk memberi nafkah kepada keluarganya yang tidak mampu. Hal ini menunjukkan hukum warisan Islām memberikan jaminal sosial bagi keluarga yang tidak mampu.

\section{DAFTAR KEPUSTAKAAN}

Ar Rofi'i, Abdul Qodir. 2000. Wahyul Qolam. Beirut: Darul Kutub Al Ilmiyyah.

Abdurrahman Al Jaziri, Al Fikih Ala Mazahib Al Arbaah (Beirut : Darul Kutub Al Ilmiyyah, 2003)

Abdurrahman As Saadi, Taisirul Karim Ar Rahman Fi Tafsir Kalamil Manan (Beirut : Muassasah Risalah $2000 \mathrm{M}$ )

Abu Dawud, Sunan Abi Dawud (Beirut: maktabah Al Asriyyah, TT) Muhaqqiq : Muhyiddin Abdul Hamid.

Abu Husain, Mu’jam Maqoyis Al Lughoh (Beirut : Darul Fikr, 1979) Muhaqqid :Abdul Salam Harun.

Abu Nash Muhammad, I'lamun Nubala' Bi Ahkami Mirats An Nisā', (San'a : Al Muthakhosis, $2004 \mathrm{M})$

Abu Utsman Al Jahidz, Tahzib Al Akhlak (Iskandariyya : Darur Shohabah Li Turats, 1989 M)

Abu Yahya As Sunaiki, Astna Muthollib Fi Syarh Raudhotul Tholib (Mesir : Darul Kitab Al Islāmi, TT)

Ad Dasuqi, Hasyiyah Ad Dasuqi Ala Syarh Al Kabir, (Beirut: Darul Fikr, TT)

Al Baghowi, Al Mālimul Tanzil Fi Tafsir Al-Qurān , Al Muhaqqiq : Abdurrazak al Mahdi (Beirut: Darul Ihya' Turats Al Arabi, $1420 \mathrm{H}$ )

Al Jurjani, At Tarifat (Beirut : Darul Kutub Al Ilmiyyah, 1983)

Amina Wadud Muhsin, Wanita Di Dalam AlQurān , Ter Yaziar Radiant (Bandung: Pustaka, 1994) 
Amir Syarifuddin, Hukum Kewarisan Dalam Islām (Jakarta: kencana, 2004)

As Sholabi, Al Mawārī̇ Fi Syariah Al Islāmiyyah Fi

Dho'I Al Kitab Wa Sunnah (Beirut: Darul Kutub Al Ilmiyyah, T'T)

Asghar Ali Engineer, Hak-Hak Perempuan Dalam Islām, Terj Farid Wajidi dan Cici Farikha Assegaf (Yogyakarta: Yayasan Benteng Budaya)

Fahruddin Ar Razi, Mafatihul Ghoib (Beirut : Darul Ihya Turats Al Ilmiyyah, $1420 \mathrm{H}$ )

Fatawa Hindiyah, (Beirut: Darul Fikr, $1310 \mathrm{H}$ )

http://www.Islāmqa.com fatwa dari Muhammad Sholih Al Munajjid No : 218831.

Ibnū Abdil Baar, Tamhid Lima Fi Al Mua'tho' (Maroko : Waziratul Waqaf Wa Syuun Al Islāmiyyah, $1387 \mathrm{H}$ )

Ibnū Jarir Ath Thobari, Jamiul Bayan Fi Ta'wil Ayyi Al-Qurān (Beirut: Muassasah Risalah, 2000 M) Muhaqqiq : Ahmad Muhammad Syakir.

Ibnū Katsir, Tafsir Al-Qurān ul Adzim (Darul Thoyyibah, $1420 \mathrm{H}$ ) Muhaqqiq : Sami Bin Muhammad Salamah.

Ibnū Mandzur, Lisanul Arab (Beirut : Darul Shodir, $1414 \mathrm{~h}$ )

Ibnū Qoyyim Al Jauziyyah, I'lamul Muwaiqiin An Rabbil Alamin (Beirut: Darul Kutub Al Ilmiyyah, $1991 \mathrm{M}$ )

Ibnū Qudamah, Al Mughni (Kairo: Maktabah Kairo, 1968)

Ibnū Qudamah, Al Muqni' Wa Syarh Al Kabir (Hijr, 1995) Tahqiq : Abdullah bin Abdul Muhsin At Turki.

Ibnū Taimiyyah, Majmu' Fatawa (Madinah : Majma Al Mulk Fahd Li Thobaah Al Mushaf As Syarif, 1995)

Ibrohim Al Maslami, Al Mawārì̇ Fil Islām (Kairo: Muthobiul Ahram Al Tijariyyah, 1989)

Jassos, Ahkamul Quran (Beirut : Darul Ihya Turats Al Arobi, 1405) Muhaqqiq : Muhammad Shodiq Al Qomhawi.

Maryam Ahmad Ad Dhaghistani, Al Mawārīì Fi Syariah Al Islāmiyyah Ala Mazahib Al Arbaah (Kairo: Universitas Al Azhar, 2001)

Muhammad Abu Zahrah, Ușūl Fikih (Darul Fikr Al Araby, TT)
Muhammad al Salum Al Hambali, Wasilatur Raghibin Wa Baghiyatul Mustafidin (Riyad : Maktabah Ar Rusyd, 1998)

Muhammad bin Abdullah Imam, Hukum Waris Wanita, (Jakarta: Embun, 2008)

Muhammad Syahrur, Metodologi Fikih Islām Kontemporer, Terj Dr. Phil Sahiron Syamsuddin, MA \& Buhanuddin (Yogyakarta: eLSAQ Press, 2008)

Munawir Sjadzali, MA, Kontekstualisasi Ajaran Islām (IPHI/PARAMADINA,1995)

Musnad Abu Dawud, Muhaqqiq : Abdul Muhsin Turki (Mesir: Darul Hijr 1999 M)

Nashr Farid Muhammad, Fikih Mawārīis Wal Wasiyah Fi Syariah Al Islmiyyah (Mesir: Maktabah Taufiqiyyah, $1416 \mathrm{H}$ )

Rasyid Ridha, Tafsir Al-Qurān Al Hakim (Tafsir Al Manar) (Mesir: Haiatu Al Misriyyah Al Amah, $1990 \mathrm{M})$

Razaq Makhur Al Gharawi, Muhasabah Al Mirats Wifqo An Nizham Al Itishodi Al Islāmi Ru'yah Muhasibiyah Islāmiyah Muashirah, Jurnal Akutansi Ekonomi Islām Di Universitas Zaitona, Yordania Tahun 2013. 56

Sarkhosy, Ușūl Sarkhosy (Beirut: Darul Ma'rifh, TT)

Sayid Qutub, Al Adalah Al Ijtimaiyyah Fil Islām Ter : Keadilan Social Dalam Islām. Penerjemah : Afif Muhammad (Bandung: Perpustakaan Salman ITB, 1984)

Sayyid Sabiq, Fikih Sunnah (Kairo: Al Fath Lil I'lami Al Arabi, T'T)

Sholahuddin Sulthon, Miratsul Marah Wa Qodiyatul Musawah (Mesir: Nuhdhoh Mesir, $1999 \mathrm{M})$

Sholih Fauzan, Tahqiqot Al Mardiyyah Fil Mabahist Al Fardiyyah (Riyad: Maktabah Maarif, 1986)

Suparman Usman, Fikih Mawārīt Hukum Kewarisan Islām (Jakarta:Gaya Media Pratama, 1997)

Syanqithi, Adwaul Bayan Fi Idhohi Al-Qurān Bil Quran (Beirut: Darul Fikr, 1995)

Syarbini, Mughni Muhtaj, (Kairo:Mustafa Al Baby Al Halaby, 1958)

Tutik Hamidah, Fikih Perempuan Berwawasan Keadilan Gender (Malang, UIN Maliki, 2011) 
Umar bin Fayhan Al Marzuqi, Iqtishodiyyat Al Mirats Fi Al Islām, Jurnal Ilmiyyah Ekonomi Islām Universitas Kairo, Mesir.vol 5, no. 14, $1422 \mathrm{H} / 2001 \mathrm{M}$.

Wahbah Zuhaili, Tafsir Wasith (Damaskus: Darul Fikr, $1422 \mathrm{H}$ )

Yahya bin Said Al Hasani, Al Muhasabah Fi Syarikat Al Asykhos (Mesir: Al Maktab Al Jami' Al Hadīis, 2006).

Yusuf Qordhawi, Musykilatul Fakir Wa Kaifa Alajahal Islām (Beirut: muasasah risalah, 1985 M)

Zamakhsyari, Al Kasyaf An Haqoiqi Ghowamidul Tanzil, (Beirut: Darul Kutub Al Arabi, 1407 $\mathrm{H})$

Nawawi, Minhajul Tholibin Fi Umdatil Muftin Fil Fikih, (Beirut: Dārul Fikr, 2005) 